\title{
Effects of a Humanitarian WTO Social Clause on Welfare and North-South Trade Flows
}

\author{
Axel Flasbarth and Markus Lips* \\ McKinsey \& Company / Agroscope FAT Tänikon
}

\begin{abstract}
The integration of core labour standards into the WTO has been demanded mostly on either humanitarian or fair trade grounds. Whereas the humanitarian integration of core labour standards is a question of means, the fair trade reasoning is a question of empirical relevance. This paper contributes to both questions by estimating the effects of an introduction of core labour standards by means of a general equilibrium model.

Trade sanctions in form of a tariff increase hardly reduce the import pressure for OECD countries, because trade diversion from non-violating countries occurs. A drastic reduction of child labour only has a marginal effect on trade flows. Both, trade sanctions as well as reduction of child labour leads to slight welfare losses. A relative small trade liberalization combined with a humanitarian social clause suffices to more than compensate them.
\end{abstract}

Keywords: $\quad$ Trade Policy, Economic Sanctions, Labour Standards, Child Labour JEL Codes: $\quad$ D58, F16

\section{Introduction}

A practically unanimous international consensus has been established concerning the universal human rights character of core labour standards (SCHERRER et al. 1998). This consensus has been codified in various international agreements such as the International Labour Organization (ILO) Declaration on Fundamental Principles and Rights at Work (ILO 1998). Core labour standards as mentioned in the ILO declaration include the freedom of association and the right to collective bargaining, the abolition of child labour, the elimination of all forms of forced labour and the elimination of discrimination with respect to employment (OECD 2000).

There is an extensive literature about labour standards. BHAGWATl (1996) provides an overview of frequently mentioned arguments in the debate, while LANGILLE (1997) discusses different ways of implementing them. BELSER (2000) analyzes the distributional effects, which occur from the violations of core labour standards.

\footnotetext{
The authors are grateful to HeINZ HAUSER and participants of a doctoral workshop at the World Trade Institute in Berne for helpful comments. The views presented are those of the authors and do not necessarily reflect those of McKinsey \& Company and Agroscope FAT Tänikon.
} 
The link between so-called core labour standards and trade sanctions is one of the most controversial issues facing global trade policy-makers. In the declaration of the World Trade Organization (WTO) Ministerial Conference in 1996 in Singapore the ministers recognize the International Labour Organization (ILO) as the competent body to set and deal with the core labour standards (www.wto.org). In the declaration of the WTO Ministerial Doha Conference in 2001 the above statement about core labour standards was reaffirmed. Despite the unambiguity of this statement, it cannot be assumed that the promotion of core labour standards within the framework of the multilateral trading system has been put to rest (ADDO 2002). While some argue that labour standards should be dealt with exclusively by the ILO, who uses publicity and technical assistance (BHAGWATI 2002) others demand the application of trade sanctions in order to increase pressure on violating countries (TREBILCOCK 2001).

The integration of core labour standards for humanitarian reasons would be a novelty in the WTO because the organization is not indented to improve the effetiveness of world trade regulation. It would transform the WTO into a crusader for core labour standards (TREBILCOCK 2001). Instead, humanitarian trade sanctions aim to attain goals, which only are indirectly linked to world trade. Therefore, the level of humanitarian trade sanctions cannot be oriented on the impact of labour standard violations on trade flows as it was done with antidumping duties (HAUSER and SCHANZ 1995). In light of the existing resistance against a social clause among developing countries a version with more facultative elements would be preferable (Reuss 1999). It would be more appropriate to choose trade sanctions in order to minimize costs of improving labour standard enforcement. Furthermore, the principle of proportionality in international public law demands that the level of trade sanctions is in line with the extent of human rights violations (Reuss 1999). A complete prohibition of imports similar to prison labour products according to Article XX(e) of the GATT would hardly be appropriate in light of the economic consequences for violating countries and the extent of the observed violations of core labour standards in these countries (STIRLING 1996).

Potential negative effects of trade sanctions like lower wages for children due to increased trade barriers are pointed out by JAFAREY and LAHIRI (2002) as well as by MASKUS (1997). To use sanctions against the violation of core labour standards bears the danger of protectionist misuse (ROLLO and Winters 2000; Cullen 1999). Trebilcock (2001) recommends checking the discriminatory character of sanction on the basis of the cha- 
peau in Article XX of the GATT according to the structure of production in the importing country. Nevertheless, the integration of core labour standards into the WTO has been demanded mostly on either humanitarian or fair trade grounds.

For a decision about the appropriate means for promoting international labour standards, costs and benefits of each approach should be compared. Some inferences about the possible benefits can be drawn from experiences with the social clause in the US-Generalized System of Preferences (GSP; SCHNEUWLY 2003). The mere threat of removing US-GSP preferences due to labour standard violations caused a sufficient improvement in 47 percent of the cases, in which a petition has been accepted for review (ElLIOTt 2000).

However, hardly any research exists so far on the costs of a social clause within the world trade order. WHALLEY and WIGLE (1998) take the first step by calculating an increase in tariffs by 35 percent on all labour-intensive exports from all developing countries. In their analysis they do not differentiate between countries according to how they are respecting workers' rights. HUSSAIN (2001) calculates the effect of a 25 percent reduction in child labor in the wearing apparel sector in selected Asian countries.

This paper contributes empirical evidence for three questions. First, how is trade affected by a tariff increase for violating countries? Second, what is the impact of a reduction or even an elimination of child labour? Finally, what will be the result of a potential trade agreement including a tariff reduction for non-violating countries and tariff increase for violating countries? For all questions we are interested in both welfare gains and trade flow changes.

The rest of this paper is organized as follows: Section two describes shortly the applied general equilibrium model of the Global Trade Analysis Project (GTAP). In section three, we present the used aggregation of the GTAP database. Furthermore, we elaborate the criteria in order to classify countries into violating and non-violating core labour standards respectively. The definition of all scenarios can be found in section four. In section five, we present results before we draw conclusions in the last section. 


\section{GTAP Model}

The GTAP model is a comparative static multi-sector multi-region general equilibrium model. A detailed description is provided in HERTEL (1997). Each region is depicted in the same manner. The consumer side is represented by the regional household to which the income from primary factors, tariffs and taxes is assigned. The regional household allocates its income to three agents: government, savings and private household. The latter represents all private consumers. All the agents get a constant share of the regional income, a consequence of the Cobb-Douglas function, which is applied for regional household utility maximization. The private household's consumption is depicted by the non-homothetic Constant Difference of Elasticities (CDE) function. The production side is divided into different sectors. These minimize their costs, as is depicted by a production tree with four nests. Therefore, Leontief and Constant Elasticity of Substitution (CES) functional forms are used. Applying the Armington assumption, imports are distinguished by region of origin. Furthermore, constant returns to scale and perfect competition are assumed. Regional endowments of factors are fixed. Labour and capital are considered as fully mobile across sectors. As numeraire the global factor price index is used.

The GTAP model includes two global institutions. All transportation between regions is carried out by the international transport sector. Using transport inputs from all the regions the international transport sector minimizes its costs by applying Cobb-Douglas technology. The second global institution is the global bank, which takes the savings from all the regions and purchases investment goods in all the regions depending on the expected profitability. The level of worldwide investments adjusts in order to meet changes in global savings. Accordingly, the global closure of the model is neoclassical (HERTEL et al. 1997). The welfare changes are measured by the equivalent variation.

\section{Data Aggregation}

We use version 5 of the GTAP database, which refers to the year 1997 (DImARANAn and MCDOUGALL 2002). For our analysis, we aggregate the 66 countries or rather regions and 57 sectors of the GTAP database to eight regions and eight sectors. The aggregation of sectors is displayed in Table 1 . It is similar to the aggregation used by MCDOUgall and TYERS 
(1997), who analyze the influence of increasing trade with developing countries on income distribution in industrialized economies. Besides agriculture and mining all industrial products are grouped in four sectors according to their average factor intensities in industrial countries. The aggregation aims to maximize the differences in factor payment cost shares between sectors. For example, while the apparel sector has a high share of labour payments, leather and wood processing are industries with medium labour intensity. Food processing and chemical goods are examples for sectors with low and very low labour intensity, respectively. Services are split into two sectors according to their factor payment cost shares. A detailed overview of the aggregation of all sectors is provided in the appendix.

Table 1 Eight Sectors

\begin{tabular}{|l|l|}
\hline Abbr. & Sector \\
\hline AGR & Agriculture \\
\hline $\mathrm{MIN}$ & Mining \\
\hline $\mathrm{IHLI}$ & Industries highly Labour-intensive \\
\hline $\mathrm{IMLI}$ & Industries medium Labour-intensive \\
\hline $\mathrm{IHCl}$ & Industries highly Capital-intensive (very low Labour Intensity) \\
\hline $\mathrm{IMCl}$ & Industries medium Capital-intensive (low Labour Intensity) \\
\hline $\mathrm{SLI}$ & Services labour-intensive \\
\hline $\mathrm{SCl}$ & Services capital-intensive (non-tradable) \\
\hline
\end{tabular}

Within the Organization for Economic Co-operation and Development (OECD) we define three regions (EU, USA and rest of OECD; Table 2). Transformation countries build the region (TRANS). Developing countries, which do not violate core labour standards, form the region DEV, while violating countries are aggregated in three regions. Classification of violating countries could be based on ratification of the relevant ILO convention. But since the ILO has practically no enforcement mechanism, ratification of conventions has only a weak influence on actual observance of labour standards (FLANAGAN 2002). Some countries are sufficiently observing ILO conventions but are refusing to ratify the corresponding conventions because ILO conventions do not only codify aims and standards but also the means to achieve them (MORICI and SCHULZ 2001). In contrast, other countries regard the ratification of the ILO convention merely as an act of will, while at the same time tolerating large deviations. Therefore, we try to classify violating countries on the basis of the degree, in which core labour standards are actually observed in prac- 
tice. ${ }^{1}$ However, it has to be kept in mind that no universally accepted definition exist of what would be a violation of core labour standards. Although a consensus exists on their universal applicability, specific details are still unclear (TREBILCOCK 2001). Countries, which violate trade union rights, are included in region $U$. The applied criteria are explained later on. Region $\mathrm{C}$ encompasses countries, whose share of working children between 10 and 14 years is above the threshold of 15 percent. ${ }^{2}$ Table 2 includes the total share of child labour for all regions. Finally, region $\mathrm{U}+\mathrm{C}$ includes countries, which violate both trade union rights and the prohibition of child labour.

Table 2 Eight Regions

\begin{tabular}{|l|l|r|r|r|}
\hline Abbrev. & Region & $\begin{array}{l}\text { Share of Global } \\
\text { GDP in Percent }\end{array}$ & $\begin{array}{l}\text { Export Share of } \\
\text { Production } \\
\text { Percent }\end{array}$ & $\begin{array}{l}\text { Share of } \\
\text { Child Labour } \\
\text { in Percent }\end{array}$ \\
\hline EU & EU & 27.5 & $16.2^{1}$ & 0 \\
\hline USA & USA & 27.4 & 5.9 & 0 \\
\hline rOECD & $\begin{array}{l}\text { Rest of OECD-countries (except Turkey, Mex- } \\
\text { ico, Czech Republic and Hungary) }\end{array}$ & 21.4 & 9.9 & 0 \\
\hline TRANS & Transformation Countries & 3.0 & 14.4 & 0 \\
\hline DEV & Non-violating Developing Countries & 7.7 & 17.0 & 2.6 \\
\hline U & Countries, which violate Trade Union Rights & 7.9 & 12.6 & 1.7 \\
\hline C & Countries with Child Labour & 3.5 & 5.8 & 4.6 \\
\hline U+C & $\begin{array}{l}\text { Countries, which violate Trade Union Rights and } \\
\text { with Child Labour }\end{array}$ & 1.5 & 16.4 & 7.8 \\
\hline
\end{tabular}

1 This number also includes trade among EU countries.

Source: Dimaranan and McDougall (2002), ILO (1996), United Nations (1997, 2001a, 2001b), WORLD BANK (2000) and own calculations.

A country or region is classified as violating trade union core labour standards if at least one of four following criteria is not met.

1 See KUCERA (2001a and 2001b) for a similar, more detailed approach, in which observance of core trade union rights is classified according to 37 weighted criteria.

2. Data are for 1998 (total population), 1997 (share of working children) and 1995 (share of total working population). In case of missing data, the last available year is used. Due to a lack of available data only working children between 10 and 14 years are considered. Generally speaking, children below 10 years work much less and also have a significant lower productivity. A more disturbing lack of official statistics is the frequent underreporting of child labour due to insufficient resources or political reasons. They can be sizeable. While ILO-figures for Vietnam indicate 8 percent child labour in 1997, the Vietnam Living Standard Survey based on 4.000 households estimates that 14 percent of all children between 6 and 15 years are working outside of their household, while further 25 percent work in their own family's business or in agriculture (EDMONDS and PAVCNIK 2001). In order to partly compensate these shortcomings, we assume that all children are working full time with average productivity. This assumption tends to overestimate child labour, because working children usually have less than average productivity and are often working less than full time. 
- First, the right to form free trade unions is violated if either founding a trade union is significantly impaired by law or in practice or if existing trade unions are heavily controlled by governmental or employer organizations. ILO convention No. 87 demands that acceptance of a trade union should not require government registration. However, for our purposes deviations are only counted as violations if the requirement for registration is used in practice to continuously prevent the formation of trade unions. Only national or sectoral limitations are considered, e.g. in export processing zones. Regulations, which restrict the maximum number of unions per company to one, as it is common in Latin American countries or in South Korea are not considered as violating as long as these trade unions can act independently.

- Second, although the right to strike is not explicitly included in the ILO conventions No. 87 and 98 we use it as a criterion. Restrictions on the right to strike are sufficient for classifying a country as violating for the purpose of this paper, if strikes are either prohibited by law or significantly impaired by legal obligations. Since legal obligations on the right to strike exist in practically all countries, we only classify obligations as violating if they are so demanding that the vast majority of strikes can only be conducted illegally and participating workers are systematically prosecuted and punished. A ban on strikes in essential sectors such as defense industries or public services is not sufficient for violating this criterion.

- Third, protection of discrimination for trade union members is not provided if participating members have to fear repressions in the form of job loss, imprisonment or even physical violence without adequate protection by the judicial system. Countries, for which widespread repressions have been reported over a sustained period of time, are classified as violating countries.

- Fourth, countries, in which the right to bargain collectively either does not exist by law or is severely restricted by government intervention are also classified as violating. Partial limitations for specific companies with pioneer status as in Malaysia are not sufficient.

For the classification of the countries two reports of the OECD (1996, 2000) are used. ${ }^{3}$ In addition, reports on observance of core labour stand-

3 In OECD (1996) observance of core trade union rights in 75 countries is classified on the basis of ILO Committee of Experts on the Application of Conventions and Recommendations (CEACR) and other reports ranging from 1 (full observance in law and practice) to 4 (trade union rights practically nonexistent). In OECD (2000) these classifications are updated to reflect new developments. For the purpose of this paper, all countries in category 4 are automatically classified as violating, while categories 1 and 2 are automatically classified as non-violating. 
ards submitted by the International Confederation of Free Trade Unions (ICFTU) for the WTO Trade Policy Review Mechanism have been employed (ICFTU, several years and 2002). Finally, a country is also classified as a violating one, if US-GSP preferences have been removed due to the violation of trade union rights (ELLIOTT 2000; SCHNEUWLY 2003).

An overview of each countries' classification based on the four chosen criteria as well as the percentage share of working children is given in the appendix. In the case that a GTAP-region includes several countries, which are not classified in the same way, the whole region is classified using total population as weights. ${ }^{4}$ For the aggregation as well as the scenarios later on we do not consider forced labour and discrimination of employment. The reason is the lack of data. In order to illustrate economic characteristics of all regions, Table 2 shows regions' shares of global GDP as well as export share of the domestic production (DIMARANAN and MCDOUgall 2002).

\section{Scenarios}

Different justifications for integrating a social clause into the world trade order have different implications for its institutional design. While a social clause, which aims to prevent unfair trade or tries to promote further trade liberalization should primarily focus on correcting trade flows, humanitarian trade sanctions should have a broader scope. For humanitarian trade sanctions it is not relevant whether the violation of core labour standards occurs in export, import competing or non-tradable industries and companies. Such sanctions are not geared towards correcting actual or assumed effects of labour standard violations on import countries but are used to create incentives for political improvements in violating countries. Table 3 gives an overview of all scenarios.

4 For instance, such a weighting is necessary for the GTAP region "Rest of North Africa". Egypt and Libya do not respect trade union rights sufficiently, while Tunisia observes them correctly and Algeria's situation could not be assessed based on the available information. Since more inhabitants in this region come from violating countries, the whole region is classified as violating trade union standards. Consequently, the GTAP region "Rest of North Africa" belongs to region $U$ in our aggregation. 
Table 3 Definition of Scenarios

\begin{tabular}{|c|c|c|}
\hline \multicolumn{2}{|l|}{ Scenario } & Definition \\
\hline \multirow{3}{*}{ Worst-Case } & $1 \mathrm{a}$ & Tariff Increase of 50 Percent in Non-violating Countries for Regions $U$ and $U+C$ \\
\hline & $1 \mathrm{~b}$ & Tariff Increase of 50 Percent in Non-violating Countries for Regions $C$ and $U+C$ \\
\hline & 1c & Tariff Increase of 50 Percent in Non-violating Countries for Regions $U, C$ and $U+C$ \\
\hline \multirow{3}{*}{ Best-Case } & $2 a$ & Reduction of Child Labour by 50 Percent \\
\hline & $2 b$ & Reduction of Child Labour by 100 Percent \\
\hline & 3 & $\begin{array}{l}\text { Tariff Reduction of } 20 \text { Percent in Non-violating Countries and Tariff Increase in } \\
\text { Non-violating Countries of } 20 \text { Percent for Regions } U, C \text { and } U+C \text { (equals a } 50 \\
\text { Percent higher Tariff for Violating Countries) }\end{array}$ \\
\hline
\end{tabular}

In scenario 1 we introduce a humanitarian clause, which requires an improvement of core labour standards. We simulate the worst-case, the case of non-improvement. Accordingly, we introduce a tariff increase of 50 percent in non-violating countries for imports from violating countries. This scenario is based on the assumption that no violating country improves its core labour standards despite the trade sanctions. We further assume that trade sanctions are levied on all exports of all violating countries. A sector specific application of the humanitarian trade sanctions would considerably reduce their efficacy. For instance, if sanctions on child labour were only applied on violations in export sectors, affected children would simply move to employment opportunities in non-exporting sectors. Assuming full labour mobility between sectors those sanctions would have no effect on exports, wages or welfare. Consequently, no incentives would be created for governments of violating countries to reduce child labour.

Scenario 1 is calculated in three versions: tariff increases for countries, which violate trade union rights (scenario 1a, Table 3 ), tariff increases for countries, which violate the prohibition of child labour (scenario 1b) and tariff increases for violating countries, which violate at least one of them (scenario 1c).

Since it cannot be foreseen in advance, which violating countries will react to the economic pressure of trade sanctions and improve their labour standards, a context-specific quantification is not possible on a global basis as it is carried out by MAskus et al. (1996) for improved trade union rights in Mexico.

A social clause in the WTO bears the danger of being misused for protectionist purposes. This is especially acute for developing countries, which 
observe core labour standards sufficiently, but could be sanctioned unjustifiably by industrialized countries in order to protect their domestic industries (Bhagwati 1995; Srinivasan 1998; ElliotT 2001). Scenario 1, estimates the additional protection northern countries could gain by misusing a social clause in this way. The relevance of a protectionist misuse depends on two effects: On the one hand, how elastic react violating country exports to increased tariffs. On the other hand, we have to take account of trade diversion from non-violating developing or industrialized countries (TREBILCOCK and Howse 1999).

Scenario 2, our best-case scenario, simulates a reduction or rather elimination of child labour. We assume the total labour supply is to be reduced by children's labour supply. While in scenario 2 a child labour is reduced by 50 percent, we eliminate it completely in scenario $2 \mathrm{~b}$. Accordingly, we reduce total labour supply in all regions, in which child labour is observed today (DEV, U, C and $\mathrm{U}+\mathrm{C}$; Table 3), irrespective of whether the region has been classified as violating the prohibition of child labour. Due to the improvement in labour standards, no trade sanctions are applied in this scenario. Hence, scenario 2 calculates the impact of global child labour on international trade flows and can assess the justification for international core labour standards based on unfair trade.

Scenario 2 also indicates how important child labour is for international trade flows and their distributional effects in the developed world. By reducing or fully eliminating children's labour supply we simulate how pressure in OECD countries would develop if the threat of trade sanctions were to achieve significant progress in the struggle against child labour. As a best-case version of humanitarian trade sanctions scenario 2 allows us to check the robustness of the results of scenario 1.

Scenario 3 combines humanitarian trade sanctions with a general tariff cut in a new world trade round. Tariffs in non-violating countries are cut by 20 percent, while non-violating countries impose a 20 percent additional tariff for violating country imports. Tariffs in violating countries are not changed in this scenario. Accordingly, scenario 3 combines negative incentives for violating countries with positive incentive for non-violating countries. Scenario 3 refers to the argument, that integrating a social clause into the WTO could increase the willingness of industrial countries to continue trade liberalization in labour-intensive industries. Conditioning market access on adherence to internationally set standards might undermine resistance from important interest groups to further liberalization 
and increase the legitimacy of trade liberalization in the public's eye (RODRIK 1996)..$^{5}$

\section{Results}

Tables 4 and 5 show the equivalent variation in million USD and as percentage change of the GDP of the base year (1997) respectively. Global trade flows have not changed by much in all scenarios. In Table 6 percent changes of regional exported values are given for each scenario, while Table 7 shows the referring imported value changes. Output value changes for all regions are provided in the appendix.

Table 4 Equivalent Variation in Mill. USD

\begin{tabular}{|l|r|r|r|r|r|r|}
\hline & \multicolumn{3}{|c|}{ Scenario 1 } & \multicolumn{2}{c|}{ Scenario 2 } & Scenario 3 \\
\hline Region & \multicolumn{1}{|c|}{$1 \mathrm{a}$} & \multicolumn{1}{c|}{$1 \mathrm{~b}$} & \multicolumn{1}{c|}{$1 \mathrm{c}$} & $2 \mathrm{a}$ & \multicolumn{1}{c|}{$2 \mathrm{~b}$} & \\
\hline EU & 3523 & 1733 & 4125 & 420 & 847 & 4305 \\
\hline USA & 3420 & 1377 & 3925 & 102 & 211 & 2256 \\
\hline rOECD & 1477 & 863 & 1898 & 78 & 161 & 6564 \\
\hline TRANS & 82 & 154 & 130 & -52 & -102 & 1819 \\
\hline DEV & 1452 & 562 & 1559 & -12701 & -25499 & 2496 \\
\hline U & -17388 & 5 & -16474 & -10139 & -20324 & -8968 \\
\hline C & 333 & -6554 & -4860 & -11734 & -23617 & -2887 \\
\hline U+C & -3011 & -3954 & -2849 & -6195 & -12577 & -1773 \\
\hline Total & -10111 & -5816 & -12545 & -40221 & -80900 & 3812 \\
\hline
\end{tabular}

Source: Own calculations

Table 5 Change of Welfare (Equivalent Variation) in Percent

\begin{tabular}{|l|r|r|r|r|r|r|}
\hline & \multicolumn{3}{|c|}{ Scenario 1 } & \multicolumn{2}{|c|}{ Scenario 2 } & Scenario 3 \\
\hline Region & \multicolumn{1}{|c|}{$1 \mathrm{a}$} & \multicolumn{1}{c|}{$1 \mathrm{~b}$} & \multicolumn{1}{c|}{$1 \mathrm{c}$} & \multicolumn{1}{c|}{$2 \mathrm{a}$} & \multicolumn{1}{c|}{$2 \mathrm{~b}$} & \\
\hline EU & 0.04 & 0.02 & 0.05 & 0.005 & 0.01 & 0.05 \\
\hline USA & 0.04 & 0.02 & 0.05 & 0.001 & 0.003 & 0.03 \\
\hline rOECD & 0.02 & 0.01 & 0.03 & 0.001 & 0.003 & 0.11 \\
\hline TRANS & 0.01 & 0.02 & 0.01 & -0.006 & -0.01 & 0.21 \\
\hline DEV & 0.06 & 0.03 & 0.07 & -0.57 & -1.14 & 0.11 \\
\hline U & -0.76 & 0.0002 & -0.72 & -0.44 & -0.89 & -0.39 \\
\hline C & 0.03 & -0.64 & -0.47 & -1.14 & -2.30 & -0.28 \\
\hline U+C & -0.69 & -0.91 & -0.65 & -1.42 & -2.89 & -0.41 \\
\hline
\end{tabular}

\section{Source: Own calculations}

5 To agree on integrating intellectual property rights in the Uruguay Round helped developing countries to abandon the Multi-Fibre-Agreement. A similar deal could be envisioned in a new trade round. Developing countries could demand further liberalization in critical sectors to compensate for their agreement to a WTO social clause (BROWN et al. 2002). 
Table 6 Changes of exported Values in Percent

\begin{tabular}{|l|r|r|r|r|r|r|}
\hline & \multicolumn{3}{|c|}{ Scenario 1 } & \multicolumn{2}{c|}{ Scenario 2 } & Scenario 3 \\
\hline Region & \multicolumn{1}{c|}{$1 \mathrm{a}$} & \multicolumn{1}{c|}{ 1 $\mathrm{b}$} & \multicolumn{1}{c|}{ 1 } & \multicolumn{2}{c|}{$2 \mathrm{a}$} & \multicolumn{2}{c|}{$2 \mathrm{~b}$} & \\
\hline EU & 0.02 & 0.05 & 0.05 & -0.10 & -0.20 & 0.29 \\
\hline USA & -0.40 & -0.06 & -0.41 & -0.21 & -0.42 & 0.78 \\
\hline rOECD & -0.34 & -0.01 & -0.33 & -0.19 & -0.39 & 1.12 \\
\hline TRANS & -0.10 & -0.01 & -0.12 & -0.15 & -0.31 & 1.89 \\
\hline DEV & -0.20 & -0.02 & -0.23 & -0.44 & -0.88 & 1.21 \\
\hline U & -3.60 & -0.08 & -3.43 & -0.28 & -0.56 & -1.82 \\
\hline C & -0.45 & -4.97 & -4.02 & 0.48 & 0.99 & -1.95 \\
\hline U+C & -2.77 & -3.31 & -2.60 & -0.65 & -1.30 & -1.56 \\
\hline
\end{tabular}

Source: Own calculations

Table 7 Changes of imported Values in Percent

\begin{tabular}{|l|r|r|r|r|r|r|}
\hline & \multicolumn{3}{|c|}{ Scenario 1 } & \multicolumn{2}{c|}{ Scenario 2 } & Scenario 3 \\
\hline Region & \multicolumn{1}{|c|}{$1 \mathrm{a}$} & \multicolumn{1}{c|}{$1 \mathrm{~b}$} & \multicolumn{1}{c|}{$\mathrm{c}$} & \multicolumn{2}{c|}{$2 \mathrm{a}$} & \multicolumn{2}{c|}{$2 \mathrm{~b}$} & \\
\hline EU & 0.11 & 0.12 & 0.18 & -0.02 & -0.03 & 0.29 \\
\hline USA & -0.10 & 0.12 & -0.03 & -0.02 & -0.05 & 0.57 \\
\hline rOECD & -0.29 & 0.10 & -0.21 & -0.04 & -0.07 & 1.47 \\
\hline TRANS & -0.003 & 0.05 & -0.02 & -0.02 & -0.04 & 3.17 \\
\hline DEV & -0.21 & -0.01 & -0.25 & -0.55 & -1.11 & 1.45 \\
\hline U & -4.34 & -0.07 & -4.08 & -0.45 & -0.89 & -2.38 \\
\hline C & -0.10 & -6.35 & -4.79 & -1.57 & -3.17 & -2.94 \\
\hline U+C & -3.15 & -3.94 & -2.92 & -1.24 & -2.53 & -1.95 \\
\hline
\end{tabular}

Source: Own calculations

\subsection{Scenario 1}

Scenario 1, our worst-case scenario, shows the costs of humanitarian trade sanctions for violating countries and the additional import protection for OECD countries. Welfare of industrialized and non-violating developing countries raises slightly in all three versions of scenario 1 (Table 4). Reasons include reduced competition in export markets and tariff rates moving closer to optimal tariff levels in some sectors. Welfare in violating countries is reduced by 0.5 to 1 percent (Table 5). Based on the experiences with the social clause in the US-GSP we can conclude that this welfare change is a strong incentive for the core labour standard enforcement. The mere threat of removal of GSP-trade preferences on exports amounting to $0.5-0.6$ percent of GDP were sufficient to achieve satisfactory improvements in almost half of the countries under review (SCHNEUwLY 2003). The tariff increase leads to a decline in violating country exported values by only 3 to 5 percent (Table 6). However, it has to be kept in 
mind that tariffs in industrial countries are already very low for many products so that even a tariff increase of 50 percent does not change significantly their prices relative to domestic goods. ${ }^{6}$ For all violating countries imported values decline up to 6 percent (Table 7 ).

In Table 8 we aggregate imported value changes of the regions EU, USA and OECD in order to get the OECD import change. Due to increased tariffs, OECD imported values from violating countries decrease by almost 4 percent (scenarios 1a and 1c, Table 8 ) and 0.5 percent (scenario 1b). Taking into account that imported values from violating countries amount to only 15 percent of all OECD imports, the decreases in scenarios 1 a and $1 \mathrm{c}$ are between 0.5 and 0.6 percent of total OECD imports. In addition, a significant trade diversion takes place as increased imports from non-violating and also OECD countries compensate for this import reduction.

Table 8 Change of aggregated imported Values in Percent (Scenario 1)

\begin{tabular}{|l|r|r|r|r|}
\hline & \multicolumn{2}{|c|}{$\begin{array}{c}\text { Share of OECD } \\
\text { Imports in \% }\end{array}$} & \multicolumn{3}{|c|}{ Change of imported Values in \% } \\
\cline { 3 - 5 } & & Scenario 1a & Scenario 1b & Scenario 1c \\
\hline OECD Imports from OECD Countries & 10.7 & 0.56 & 0.22 & 0.71 \\
\hline OECD Imports from TRANS and DEV & 14.3 & 0.65 & 0.25 & 0.80 \\
\hline OECD Imports from Violating Countries & 15.0 & -3.43 & -0.48 & -3.84 \\
\hline \hline Total OECD Imports & 100 & -0.03 & 0.12 & 0.04 \\
\hline
\end{tabular}

Source: Dimaranan and McDougall (2002) and own calculations

All changes of OECD imported values mentioned so far are based on the weighted sum of changes in all sectors. In Table 9 we present sector specific imported value changes for the OECD, which is again the weighted sum of EU, USA and rOECD. All changes are modest. In scenario 1c, even imports in the two sectors with the highest tariffs, AGR and IHCI, are only slightly reduced. It has to be kept in mind that the sector classification of the GTAP database cuts off tariff peaks. ${ }^{7}$ Especially in agriculture and processed food, significant trade barriers still exist, which are far above average. Therefore, most of the effects of humanitarian trade sanctions are concentrated on a few goods with tariff peaks, for which an import protection effect of such sanctions could potentially exist, although they would not show up in our results.

6 Except the sectors AGR and $\mathrm{IHCl}$, which includes processed food the tariffs are modest. For example in the EU the tariffs for the sectors MIN, IHLI, IMLI, IMCI are between 0 and 1.7 percent (DIMARANAN and MCDOUGALL 2002). The referring range for the USA is between 0.2 and 4.2 percent.

7 This is aggravated by the fact that high tariffs reduce corresponding imports so that tariff peaks are underrepresented when average tariff rates are used (RODRIK and RODRIGUEZ 2000). 
Table 9 Sectoral Value Changes of OECD Imports in Percent (Scenario 1)

\begin{tabular}{|l|r|r|r|}
\hline Sector & Scenario 1a & Scenario 1b & Scenario 1c \\
\hline AGR & -0.73 & -0.07 & -0.89 \\
\hline MIN & -0.26 & -0.0004 & -0.24 \\
\hline $\mathrm{IHLI}$ & 0.04 & 0.15 & 0.13 \\
\hline $\mathrm{IMLI}$ & -0.46 & 0.03 & -0.43 \\
\hline $\mathrm{IHCl}$ & -1.19 & -0.61 & -1.39 \\
\hline $\mathrm{IMCl}$ & 0.15 & 0.16 & 0.23 \\
\hline SLI & 0.52 & 0.30 & 0.67 \\
\hline SCl & 0.24 & 0.17 & 0.33 \\
\hline Total OECD Imports & -0.03 & 0.12 & 0.04 \\
\hline
\end{tabular}

Source: Own calculations

The increase of total imported values in OECD countries in scenarios $1 \mathrm{~b}$ and 1c (Tables 8 and 9), which occurs despite a tariff increase for some trading partners seems to be counter-intuitive. The overcompensation of trade reduction by tariff diversion can largely be explained with changes in factor allocation in developing countries. A tariff increase of 50 percent raises import prices of goods with high initial tariffs relative to products with low initial tariffs. This change of relative import prices induces a shift of resources in violating countries out of sectors with high initial tariffs (AGR and IHCI). Given a decrease of factor prices, imported values in OECD countries raise for low-tariff goods (Table 9), while OECD imports in other sectors decline due to the tariff increases for violating countries. Since total trade flows only change marginally, the factor reallocation effect is able to overcompensate the trade reducing effect of the tariff increase.

\subsection{Scenario 2}

Scenario 2 simulates the reduction or rather elimination of global child labour. The welfare effects of a reduction of child labour are significant. Complete elimination of child labour leads to welfare losses between 1.0 and 2.9 percent in regions $\mathrm{DEV}, \mathrm{U}, \mathrm{C}$ and $\mathrm{U}+\mathrm{C}$ (Table 5). To compensate for this loss approximately 82 billion USD would be necessary to be transferred to developing countries (Table 4). Otherwise, poverty would aggravate in these regions. The reduction of welfare consists of two effects. The main effect is the reduction of the factor supply of unskilled labour since some or all of the children are no longer working. In other words, a part of income is lost. In addition, differences in factor supply between countries with and without child labour are reduced. It results an 
efficiency loss from international trade. However, the loss of welfare due to labour supply reduction has to be compared with the utility increase of children not working any more, which is not included in our calculation. This utility gain compensates at least partly for the output reduction. But if one accepts the universal consensus on the non-acceptance of child labour, this utility gain would more than compensate the loss in utility terms. Consequently, only the welfare reduction from international trade between countries with more similar factor endowments would count as the true costs of abolishing child labour. These costs can be expected to account only for a marginal share of the total welfare loss in the scenarios $2 \mathrm{a}$ and $2 \mathrm{~b}$ (Tables 4 and 5).

In contrast to welfare results, the effects on global trade flows are modest. Even in the unrealistic case of total abolishment of child labour (scenario $2 b$ ), exported values of regions $D E V, U, C$ and $U+C$ are reduced between 0.3 and 1.3 percent (Table 6). Region $C$ is an exception and can even increase its exported values. Due to a general price decline the exported quantities from region $\mathrm{C}$ increase and overcompensate the price effect.

The complete abolition of child labour reduces imported values in OECD countries from regions DEV, U, C and $U+C$ by 0.23 percent (Table 10 ). Total imported values to OECD countries decline in both scenarios by less than 0.05 percent. Such slight effects are not surprising in the light of low shares of child labour in total labour supply (Table 2). These changes are so small that even a significant underestimation of children's economic contribution in developing countries would not change these conclusions.

Table 10 Value Changes of aggregated imported Values in Percent (Scenario 2)

\begin{tabular}{|l|r|r|}
\hline & Scenario $2 a$ & Scenario $2 b$ \\
\hline Imports in OECD Countries from DEV, U, C and U+C & -0.12 & -0.23 \\
\hline Total OECD Imports & -0.02 & -0.04 \\
\hline
\end{tabular}

Source: Own calculations

An important implication of the low trade changes in scenario 2 is a confirmation of the outcomes of scenario 1, the worst-case. In scenario 1 OECD imports hardly change under the assumption that violating countries do not improve their core labour standards despite sanctions being levied on their imports. Now, the best-case assumption of all countries im- 
proving their enforcement of the prohibition of child labour also leads to only miniscule trade effects in developed countries. Regarding child labour it can therefore be confirmed that a WTO social clause is of hardly any use as a protectionist instrument for northern economies.

\subsection{Scenario 3}

Scenario 3 evaluates the integration of core labour standards in order to promote worldwide trade liberalization. The global welfare effect is positive (Table 4). Accordingly, a relative small liberalization suffices to more than compensate the welfare loss of a humanitarian social clause. This ratio could become even better if liberalization is focused on critical sectors with high trade barriers in industrialized countries. The welfare effects are unevenly distributed across regions. All violating regions ( $\mathrm{U}, \mathrm{C}$ and $\mathrm{U}+\mathrm{C}$ ) suffer together a welfare loss of 13.6 billion USD. Contrariwise, the nonviolating regions TRANS and DEV improve their welfare. This improvement is an incentive for violating countries to take measurements such as more and better schools and income compensation schemes for child labourers (BROWN, 2001). Reduced trade barriers for non-violating countries also improve their trade flows (Table 11). Exported values of the regions TRANS and DEV raise by 1.4 percent, while violating countries' exports are reduced by 1.8 percent on average. The referring imported values change by +1.3 percent and -2.4 percent, respectively.

Table 11 Value Changes of aggregated Trade Flows in Percent (Scenario 3)

\begin{tabular}{|l|r|r|}
\hline Region & \multicolumn{1}{|l|}{ Exports } & \multicolumn{1}{|l|}{ Imports } \\
\hline OECD Countries & 0.60 & 0.63 \\
\hline TRANS and DEV & 1.42 & 1.34 \\
\hline Violating Countries $(U, C$ and $U+C)$ & -1.85 & -2.41 \\
\hline
\end{tabular}

Source: Own calculations 


\section{Conclusions}

In this paper we estimate the effect of an introduction of core labour standards by means of a general equilibrium model.

As a result of the simulation, integration of core labour standards into the WTO will not shield industrialized countries raising import pressure from developing countries. As expected such a social clause would reduce imports from violating countries but this will be compensated by additional imports from non-violating developing or industrialized countries. Therefore, imports in OECD countries remain practically unchanged. Based on our analysis, concerns about protectionist effects of a social clause appear unfounded in their general claim. A WTO social clause could on aggregate not serve as a useful tool of import protection. Therefore, the refusal of developing countries to integrate core labour standards into the WTO, which is mainly based on this fear, is largely unfounded. Even a protectionist misuse of a social clause in industrialized countries would not lead to import reduction since reduced imports from the sanctioned country would be compensated by increased trade with other trading partners.

Quests for an integration of core labour standards into the world trade system in order to correct unfair trade flows and their distributional consequences cannot be justified on the basis of our analysis. Changes of trade flows after child labour has been halved or completely eliminated are marginal.

Integrating a social clause could potentially facilitate multilateral trade liberalization, since welfare for non-violating or enforcement-improving countries increases. At the same time the costs for non-improving countries are limited.

In light of these possible trade liberalization effects and a limited danger of protectionist misuse a multilateral humanitarian social clause could be an effective instrument to promote the century-long global quest for better worker rights. 


\section{References}

AdDo, KofI (2002), The Correlation Between Labour Standards and International Trade. Which Way Forward?, Journal of World Trade, 36(2), pp. 285-303.

Belser, PATRICK (2000), Trade, Labor Standards and Income Distribution, A Reappraisal, Working Paper, Institute of Development Studies, University of Sussex.

Bhagwati, JAGDish (1995), Trade Liberalisation and 'Fair Trade' Demands: Adressing the Environmental and Labour Standards Issues, The World Economy 18 (6), pp. 745-759.

Bhagwati, Jagdish (1996), The Demands to Reduce Domestic Diversity among Trading Nations, in: JAGdish Bhagwati und Robert HudeC (Eds.), Fair Trade and Harmonization: Prerequisites for Free Trade?, Volume 1, Economic Analysis, Cambridge, MA, pp. 9-40.

Bhagwati, Jagdish (2002), Free Trade Today, Princeton: University Press.

Brown, Drusilla K. (2001), Child Labour in Latin America: Policy and Evidence, The World Economy 24 (6), pp. 761-778.

Brown, Drusilla K., Alan V. Deardorff and Robert M. Stern (2002), The Pros and Cons of Linking Trade and Labor Standards, University of Tufts, Discussion Paper Nr. 06-2002.

Cullen, Holly (1999), The Limits of International Trade Mechanisms in Enforcing Human Rights: The Case of Child Labour, International Journal of Children's Rights 7, pp. 1-29.

Dimaranan, Betina V. and Robert A. McDougall (2002), Global Trade Assistance and Production: The GTAP 5 Data Base, Center for Global Trade Analysis, West Lafayette.

Edmonds, ERIC and NinA PAVCNIK (2001), Does Globalization Increase Child Labor? Evidence from Vietnam, Working Paper Nr. 8760, National Bureau of Economic Research.

Elliott, Kimberly A. (2000), Preferences for Workers? Worker Rights and the US Generalized System of Preferences, Mimeo, Institute for International Economics, Washington DC.

Elliott, Kimberly A. (2001), Enforcing International Labor Standards: Sunshine, Carrots, and Teeth?, Mimeo, Institute for International Economics, Washington DC.

Flanagan, Robert J. (2002), Labour Standards and International Competitive Advantage, Mimeo.

Hauser, Heinz und Kal Uwe Schanz (1995), Das neue Gatt: Die Welthandelsordnung nach Abschluss der Uruguay-Runde, München: Oldenburg. 
Hertel, Thomas W. (1997), Global Trade Analysis Modeling and Applications, New York: Cambridge University Press.

Hertel, Thomas W., Elena Ianchovichina and Bradley J. McDonALD (1997), Multi-Region General Equilibrium Modeling, in: FRANCoIs, Josef F. and Kenneth A. Reinert (Eds.), Applied Methods for Trade Policy Analysis a Handbook, New York: Cambridge University Press.

Hussain, Mahmood (2001), Child Labor and International Trade: A Computational Analysis for the Apparel Sector in Asia, Working Paper 1/01, University of Colorado.

ICFTU (several years), Country Reports for the ILO, Geneva, Internet: http://www.icftu.org (as of 17 April 2006).

ICFTU (2002), Annual Survey of Violations of Trade Union Rights, Geneva.

ILO (1996), Economically Active Population 1995-2010, Geneva, $4^{\text {th }}$ Edition.

ILO (1998), Declaration on Fundamental Principles and Rights at Work, Geneva.

JAFAREy, Saqib and Sajal Lahiri (2002), Will Trade Sanctions Reduce Child Labor? The Case of Credit Markets, Journal of Development Economics 68(1), pp. 137-156.

KuCERA, DAvid (2001a), The Effects of Core Workers Rights on Labour Costs and Foreign Direct Investment: Evaluating the "Conventional Wisdom”, Institute for International Labour Studies Decent Work Research Programme, Discussion Paper Nr. 130.

KuCERA, DAVID (2001b), Measuring fundamental Rights at Work, Statistical Journal of the United Nations Economic Commission for Europe $18(2,3)$, pp. 175-186.

LANGILlE, BRIAN A. (1997), Eight Ways to Think about International Labour Standards, Journal of World Trade 31 (4), pp. 27-53.

Markus, Keith E. (1997), Should Core Labor Standards Be Imposed Through International Trade Policy?, Policy Research Working Paper Nr. 1817, World Bank.

Markus, Keith E., Thomas F. Rutherford and Steven Selby (1996), Economic Implications of Changes in Labor Standards: A Computational Analysis for Mexico, North American Journal of Economics and Finance 6, pp. 171-188.

McDougall, Robert A. and Rod Tyers (1997), Developing Country Expansion and Relative Wages in Industrial Countries, in: THOMAS W. Hertel (Ed.), Global Trade Analysis Modeling and Applications, New York: Cambridge University Press, pp. 191-211. 
Morici, Peter and Evan Schulz (2001), Labor Standards in the Global Trading System, Economic Strategy Institute, Washington DC.

OECD (1996), Trade, Employment and Labour Standards: A Study of Core Workers' Rights and International Trade, Paris.

OECD (2000), International Trade and Core Labour Standards, Paris.

ReUss, MatTHIAS (1999), Menschenrechte durch Handelssanktionen. Die Durchsetzung sozialer Standards im Rahmen der WTO, Baden-Baden: Nomos Verlag.

RoDrIK, DANI (1996), Labor Standards in International Trade: Do They Matter and What Do We Do About Them, in: RoBERT Z. LAWRENCE, DANI RODRIK and JOHN WHALlEy (Eds.), Emerging Agenda for Global Trade: High States for Developing Countries, Washington DC, pp. 35-79.

Rodrik, Dani and Francisco Rodriguez (2000), Trade Policy and Economic Growth: A Skeptic's Guide to the Cross-National Evidence, in: Ben Bernanke and Kenneth Rogoff (Eds.), NBER Macroeconomics Annual 2000, Working Paper No. 8461. Cambridge, Mass.: MIT Press.

Rollo, Jim and Alan L. Winters (2000), Subsidiarity and Governance Challenges for the WTO: Environmental and Labour Standards, The World Economy 23 (4), pp. 561-575.

Scherrer, Christoph, Thomas Greven und Volker Frank (1998), Sozialklauseln: Arbeitnehmerrechte im Welthandel, Münster: Verlag Westphälisches Dampfboot.

SChNeuwly, Philippe (2003), Sind Handelssanktionen ein geeignetes Mittel zur Durchsetzung von Arbeitsnormen? - Eine Untersuchung der Wirksamkeit der Sozialklausel im US GSP, Aussenwirtschaft 58 (1), S. 121-144.

SRINIVASAN, T. N. (1998), Developing Countries in the Multilateral Trading System, Boulder: Westview Press.

Stirling, Patricia (1996), The Use of Trade Sanctions as an Enforcement Mechanism for Basic Human Rights: A Proposal for Addition to the World Trade Organization, American University Journal of International Law and Policy 11 (1), pp. 1-46.

Trebilcock, Michael J. (2001), Trade Policy and Labour Standards: Objectives, Instruments and Institutions, Law and Economics Working Paper Nr. 02-01, University of Toronto.

Trebilcock, Michael J. and Robert Howse (1999), The Regulation of International Trade, London: Routledge, $2^{\text {nd }}$ Edition.

United Nations (1997), Demographic Yearbook 1995, New York, 47 $7^{\text {th }}$ Edition. 
United Nations (2001a), Demographic Yearbook 1999, New York, $51^{\text {st }}$ Edition.

United Nations (2001b), Statistical Yearbook 1998, New York, 45 ${ }^{\text {th }}$ Edition.

Whalley, John and Randall M. Wigle (1998), Labour Standards and Trade: Preliminary Estimates, in: HARMON, ThOMAs and JOHN WHALLEY (Eds.), Uruguay Round Results and the Emerging Trade Agenda, Geneva: United Nations, pp. 477-491.

Worlo BANK (2000), World Development Indicators, Washington DC. 


\section{Appendix}

Table 12 Aggregation of Sectors

\begin{tabular}{|c|c|c|}
\hline \multicolumn{2}{|c|}{ Sector } & \multirow[b]{2}{*}{$\begin{array}{l}\text { Commodities } \\
\text { Paddy rice } \\
\text { Wheat } \\
\text { Other cereals } \\
\text { Vegetables, fruit, nuts } \\
\text { Oil seeds } \\
\text { Sugar cane, sugar beet } \\
\text { Plant-based fibers } \\
\text { Other crops } \\
\text { Bovine cattle, sheep and goats, horses } \\
\text { Other animal products } \\
\text { Raw milk } \\
\text { Wool, silk-worm cocoons } \\
\text { Forestry } \\
\text { Fishing }\end{array}$} \\
\hline AGR & Agriculture & \\
\hline MIN & Mining & $\begin{array}{l}\text { Coal } \\
\text { Oil } \\
\text { Gas } \\
\text { Other minerals }\end{array}$ \\
\hline IHLI & $\begin{array}{l}\text { Highly Labour-intensive } \\
\text { Industries }\end{array}$ & $\begin{array}{l}\text { Wearing apparel } \\
\text { Ferrous metals } \\
\text { Motor vehicles and parts } \\
\text { Other transport equipment } \\
\text { Electronic } \\
\text { Other machinery and equipment }\end{array}$ \\
\hline IMLI & $\begin{array}{l}\text { Medium Labour-intensive } \\
\text { Industries }\end{array}$ & $\begin{array}{l}\text { Textiles } \\
\text { Leather products } \\
\text { Wood products except furniture } \\
\text { Paper products, publishing } \\
\text { Petroleum, coal products } \\
\text { Other mineral products } \\
\text { Other metals } \\
\text { Metal products }\end{array}$ \\
\hline $\mathrm{IHCl}$ & $\begin{array}{l}\text { Highly Capital-intensive } \\
\text { Industries }\end{array}$ & $\begin{array}{l}\text { Bovine cattle, sheep and goat, horse meat products } \\
\text { Other meat products } \\
\text { Vegetable oils and fats } \\
\text { Dairy products } \\
\text { Processed rice } \\
\text { Sugar } \\
\text { Other food products }\end{array}$ \\
\hline $\mathrm{IMCl}$ & $\begin{array}{l}\text { Medium Capital-intensive } \\
\text { Industries }\end{array}$ & $\begin{array}{l}\text { Beverages and tobacco products } \\
\text { Chemical, rubber, plastic products } \\
\text { Other manufactures }\end{array}$ \\
\hline
\end{tabular}




\begin{tabular}{|c|c|c|}
\hline \multicolumn{2}{|c|}{ Sector } & Commodities \\
\hline & Labour-intensive Services & $\begin{array}{l}\text { Electricity } \\
\text { Gas manufacture, distribution } \\
\text { Water } \\
\text { Construction } \\
\text { Trade } \\
\text { Other transport } \\
\text { Water transport } \\
\text { Air transport } \\
\text { Communication } \\
\text { Other financial services } \\
\text { Insurance } \\
\text { Other business services } \\
\text { Recreational and other services } \\
\text { Public administration and defence, education, health }\end{array}$ \\
\hline $\mathrm{SCl}$ & Capital-intensive Services & Dwellings \\
\hline
\end{tabular}

Table 13 Classification of Countries

\begin{tabular}{|c|c|c|c|c|c|c|}
\hline 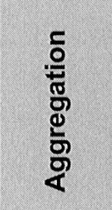 & $\begin{array}{l}\frac{5}{8} \\
\frac{0}{8} \\
\frac{0}{1} \\
\frac{1}{5} \\
\frac{5}{0}\end{array}$ & है & 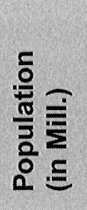 & 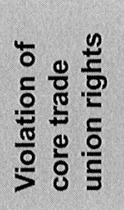 & 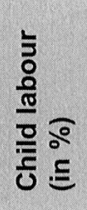 & 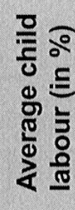 \\
\hline EU & $\begin{array}{l}\text { Austria } \\
\text { Belgium } \\
\text { Denmark } \\
\text { Finland } \\
\text { France } \\
\text { Germany } \\
\text { Greece } \\
\text { Ireland } \\
\text { Italy } \\
\text { Luxembourg } \\
\text { Netherlands } \\
\text { Portugal } \\
\text { Spain } \\
\text { Sweden } \\
\text { United Kingdom }\end{array}$ & $\begin{array}{l}\text { Austria } \\
\text { Belgium } \\
\text { Denmark } \\
\text { Finland } \\
\text { France } \\
\text { Germany } \\
\text { Greece } \\
\text { Ireland } \\
\text { Italy } \\
\text { Luxembourg } \\
\text { Netherlands } \\
\text { Portugal } \\
\text { Spain } \\
\text { Sweden } \\
\text { United Kingdom }\end{array}$ & $\begin{array}{r}8,1 \\
10,2 \\
5,3 \\
5,1 \\
58,8 \\
82 \\
10,5 \\
3,7 \\
57,4 \\
0,4 \\
15,7 \\
10,0 \\
39,4 \\
8,8 \\
58,6\end{array}$ & & $\begin{array}{l}0 \\
0 \\
0 \\
0 \\
0 \\
0 \\
0 \\
0 \\
0 \\
0 \\
0 \\
2 \\
0 \\
0 \\
0\end{array}$ & $\begin{array}{l}0 \\
0 \\
0 \\
0 \\
0 \\
0 \\
0 \\
0 \\
0 \\
0 \\
0 \\
2 \\
0 \\
0 \\
0\end{array}$ \\
\hline USA & USA & USA & 270.6 & & 0 & 0 \\
\hline rOECD & $\begin{array}{l}\text { Australia } \\
\text { New Zealand } \\
\text { Hong Kong } \\
\text { Japan } \\
\text { Korea } \\
\text { Taiwan } \\
\text { Canada } \\
\text { Switzerland }\end{array}$ & $\begin{array}{l}\text { Australia } \\
\text { New Zealand } \\
\text { Hong Kong } \\
\text { Japan } \\
\text { Korea, Republic of } \\
\text { Taiwan } \\
\text { Canada } \\
\text { Switzerland }\end{array}$ & $\begin{array}{r}18,7 \\
3,8 \\
7,0 \\
126,4 \\
46,4 \\
21,9 \\
30,2 \\
7,1\end{array}$ & & $\begin{array}{l}0 \\
0 \\
0 \\
0 \\
0 \\
0 \\
0 \\
0\end{array}$ & $\begin{array}{l}0 \\
0 \\
0 \\
0 \\
0 \\
0 \\
0 \\
0\end{array}$ \\
\hline
\end{tabular}




\begin{tabular}{|c|c|c|c|c|c|c|}
\hline 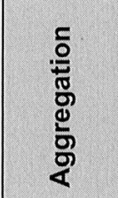 & $\begin{array}{l}\frac{5}{0} \\
\frac{0}{0} \\
\frac{\pi}{1} \\
\frac{0}{5} \\
\frac{0}{6}\end{array}$ & 站 & $\begin{array}{l}\frac{5}{0} \\
\frac{\pi}{\bar{c}} \overline{\bar{\Sigma}} \\
\frac{0}{0} \\
0 \leq\end{array}$ & 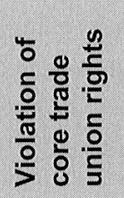 & $\begin{array}{l}\frac{1}{\bar{z}} \\
\frac{8}{\frac{0}{\pi}} \\
\frac{0}{\frac{\pi}{0}} \\
\frac{0}{0}\end{array}$ & 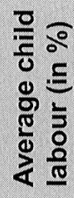 \\
\hline & Rest of EFTA & $\begin{array}{l}\text { Iceland } \\
\text { Liechtenstein } \\
\text { Norway }\end{array}$ & $\begin{array}{l}0,3 \\
0,0 \\
4,4\end{array}$ & & $\begin{array}{l}0 \\
0 \\
0\end{array}$ & 0 \\
\hline \multirow[t]{3}{*}{ TRANS } & $\begin{array}{l}\text { Hungary } \\
\text { Poland }\end{array}$ & $\begin{array}{l}\text { Hungary } \\
\text { Poland }\end{array}$ & $\begin{array}{l}10,1 \\
38,7\end{array}$ & & $\begin{array}{l}0 \\
0\end{array}$ & $\begin{array}{l}0 \\
0\end{array}$ \\
\hline & $\begin{array}{l}\text { Rest of Central } \\
\text { European Ass. }\end{array}$ & $\begin{array}{l}\text { Bulgaria } \\
\text { Czech Republic } \\
\text { Romania } \\
\text { Slovakia } \\
\text { Slovenia }\end{array}$ & $\begin{array}{r}8,3 \\
10,3 \\
22,5 \\
5,4 \\
2,0\end{array}$ & & $\begin{array}{l}0 \\
0 \\
0 \\
0 \\
0\end{array}$ & 0 \\
\hline & $\begin{array}{l}\text { Former Soviet } \\
\text { Union }\end{array}$ & $\begin{array}{l}\text { Armenia } \\
\text { Azerbaijan } \\
\text { Belarus } \\
\text { Estonia } \\
\text { Georgia } \\
\text { Kazakhstan } \\
\text { Kyrgyzstan } \\
\text { Latvia } \\
\text { Lithuania } \\
\text { Moldova, Republic of } \\
\text { Russian Federation } \\
\text { Tajikistan } \\
\text { Turkmenistan } \\
\text { Ukraine } \\
\text { Uzbekistan } \\
\end{array}$ & $\begin{array}{r}3,5 \\
7,7 \\
10,2 \\
1,4 \\
5,1 \\
15,1 \\
4,8 \\
2,4 \\
3,7 \\
3,6 \\
146,5 \\
6,0 \\
4,9 \\
50,5 \\
24,0 \\
\end{array}$ & $\begin{array}{l}\text { n.a. } \\
\text { n.a. } \\
\text { n.a. } \\
\text { n.a. }\end{array}$ & $\begin{array}{l}0 \\
0 \\
0 \\
0 \\
0 \\
0 \\
0 \\
0 \\
0 \\
0 \\
0 \\
0 \\
0 \\
0 \\
0\end{array}$ & 0 \\
\hline \multirow[t]{2}{*}{ DEV } & $\begin{array}{l}\text { Malaysia } \\
\text { Philippines } \\
\text { Singapore } \\
\text { India } \\
\text { Sri Lanka } \\
\text { Mexico } \\
\text { Peru } \\
\text { Venezuela } \\
\text { Rest of Andean } \\
\text { Pact } \\
\text { Argentina } \\
\text { Chile } \\
\text { Uruguay }\end{array}$ & $\begin{array}{l}\text { Malaysia } \\
\text { Philippines } \\
\text { Singapore } \\
\text { India } \\
\text { Sri Lanka } \\
\text { Mexico } \\
\text { Peru } \\
\text { Venezuela } \\
\text { Bolivia } \\
\text { Ecuador } \\
\text { Argentina } \\
\text { Chile } \\
\text { Uruguay }\end{array}$ & $\begin{array}{r}22,1 \\
75,1 \\
3,9 \\
970,9 \\
18,8 \\
95,8 \\
24,8 \\
23,2 \\
7,9 \\
12,2 \\
36,1 \\
14,8 \\
3,3\end{array}$ & & $\begin{array}{r}3 \\
7 \\
0 \\
13 \\
2 \\
6 \\
2 \\
1 \\
13 \\
5 \\
4 \\
0 \\
2 \\
\end{array}$ & $\begin{array}{r}3 \\
7 \\
0 \\
13 \\
2 \\
6 \\
2 \\
1 \\
8 \\
\\
4 \\
0 \\
2 \\
\end{array}$ \\
\hline & $\begin{array}{l}\text { Rest of S. African } \\
\text { Cust. Union }\end{array}$ & $\begin{array}{l}\text { Lesotho } \\
\text { Namibia } \\
\text { South Africa } \\
\text { Swaziland }\end{array}$ & $\begin{array}{r}2,1 \\
1,7 \\
42,1 \\
1,0\end{array}$ & S,D & $\begin{array}{r}22 \\
20 \\
0 \\
\text { n.a. }\end{array}$ & 2 \\
\hline
\end{tabular}




\begin{tabular}{|c|c|c|c|c|c|c|}
\hline $\begin{array}{l}\frac{5}{0} \\
\frac{0}{\pi} \\
\frac{\pi}{8} \\
\frac{d}{5} \\
\frac{5}{4}\end{array}$ & $\begin{array}{l}\frac{c}{0} \\
\frac{0}{8} \\
\frac{\alpha}{1} \\
\frac{0}{4} \\
\frac{1}{0}\end{array}$ & 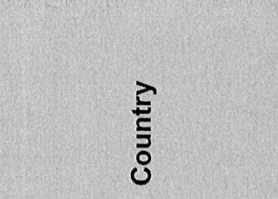 & $\begin{array}{l}\frac{5}{0} \\
\frac{0}{\pi} \\
\frac{\bar{E}}{2} \\
\frac{0}{0} \\
\square\end{array}$ & 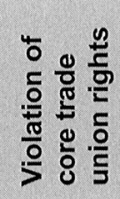 & 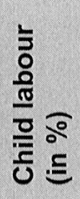 & 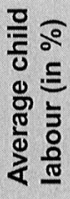 \\
\hline \multirow[t]{5}{*}{ U } & $\begin{array}{l}\text { China } \\
\text { Indonesia } \\
\text { Vietnam }\end{array}$ & $\begin{array}{l}\text { China } \\
\text { Indonesia } \\
\text { Vietnam }\end{array}$ & $\begin{array}{r}1255,7 \\
202,9 \\
77,6 \\
\end{array}$ & $\begin{array}{r}A, S, K \\
S, D \\
A\end{array}$ & $\begin{array}{r}10 \\
9 \\
8 \\
\end{array}$ & $\begin{array}{r}10 \\
9 \\
8 \\
\end{array}$ \\
\hline & $\begin{array}{l}\text { Centr. America } \\
\text { and Caribbean }\end{array}$ & $\begin{array}{l}\text { Anguilla } \\
\text { Antigua \& Barbuda } \\
\text { Aruba } \\
\text { Bahamas } \\
\text { Barbados } \\
\text { Belize } \\
\text { Cayman Islands } \\
\text { Costa Rica } \\
\text { Cuba } \\
\text { Dominica } \\
\text { Dominican Republic } \\
\text { El Salvador } \\
\text { Grenada } \\
\text { Guatemala } \\
\text { Haiti } \\
\text { Honduras } \\
\text { Jamaica } \\
\text { Netherlands Antilles } \\
\text { Nicaragua } \\
\text { Panama } \\
\text { Saint Kitts and Nevis } \\
\text { Saint Lucia } \\
\text { Saint Vincent and } \\
\text { Grenadines } \\
\text { Trinidad and Tobago } \\
\text { Virgin Islands, British }\end{array}$ & $\begin{array}{r}0,0 \\
0,1 \\
0,1 \\
0,3 \\
0,3 \\
0,2 \\
0 \\
3,3 \\
11,1 \\
0,1 \\
8,1 \\
6,0 \\
0,1 \\
10,8 \\
7,6 \\
6,2 \\
2,5 \\
0,2 \\
4,8 \\
2,8 \\
0,0 \\
0,1 \\
\\
0,1 \\
1,3 \\
0,1 \\
\end{array}$ & $\begin{array}{r}\text { n.a. } \\
\text { n.a. } \\
\text { n.a. } \\
\text { n.a. } \\
\text { n.a. } \\
\text { A,S,K } \\
\\
\text { n.a. } \\
\text { D } \\
\text { A,D,K }\end{array}$ & $\begin{array}{r}\text { n.a. } \\
\text { n.a. } \\
\text { n.a. } \\
\text { n.a. } \\
\text { n.a. } \\
\text { n.a. } \\
\text { n.a. } \\
5 \\
0 \\
\text { n.a. } \\
15 \\
15 \\
\text { n.a. } \\
15 \\
24 \\
8 \\
0 \\
\text { n.a. } \\
13 \\
3 \\
\text { n.a. } \\
\text { n.a. } \\
\text { n.a. } \\
0 \\
\text { n.a. }\end{array}$ & 11 \\
\hline & Colombia & Colombia & 36,7 & $D$ & 6 & 6 \\
\hline & $\begin{array}{l}\text { Rest of South } \\
\text { America }\end{array}$ & $\begin{array}{l}\text { Guyana } \\
\text { Paraguay } \\
\text { Suriname }\end{array}$ & $\begin{array}{l}0,8 \\
5,2 \\
0,4\end{array}$ & $\begin{array}{r}\text { n.a. } \\
\text { D }\end{array}$ & $\begin{array}{r}\text { n.a. } \\
7 \\
\text { n.a. }\end{array}$ & 7 \\
\hline & $\begin{array}{l}\text { Rest of Middle } \\
\text { East }\end{array}$ & $\begin{array}{l}\text { Bahrain } \\
\text { Iran, Islamic Rep. of } \\
\text { Iraq } \\
\text { Israel } \\
\text { Jordan } \\
\text { Kuwait } \\
\text { Lebanon } \\
\text { Oman } \\
\text { Qatar } \\
\text { Saudi Arabia } \\
\text { Syrian Arab Republic }\end{array}$ & $\begin{array}{r}0,6 \\
61,6 \\
21,8 \\
6,0 \\
6,3 \\
2,0 \\
3,2 \\
2,1 \\
0,6 \\
20,2 \\
15,6\end{array}$ & $\begin{array}{r}A, S, D, K \\
A, S \\
A, S, D, K \\
\\
\text { S } \\
\text { n.a. } \\
\text { A,S,K } \\
\text { A,K } \\
\text { A,S,K } \\
\text { A,S,K }\end{array}$ & $\begin{array}{r}\text { n.a. } \\
4 \\
3 \\
0 \\
0 \\
0 \\
0 \\
0 \\
\text { n.a. } \\
0 \\
4\end{array}$ & 5 \\
\hline
\end{tabular}




\begin{tabular}{|c|c|c|c|c|c|c|}
\hline $\begin{array}{l}\frac{c}{0} \\
\frac{0}{0} \\
\frac{0}{0} \\
\frac{0}{5} \\
\frac{7}{0}\end{array}$ & $\frac{\frac{c}{0}}{\frac{0}{1}}$ & 흘 & $\begin{array}{l}\frac{5}{\frac{0}{\pi}} \equiv \\
\frac{\pi}{3} \equiv \\
\frac{2}{0} \equiv \\
0 .\end{array}$ & 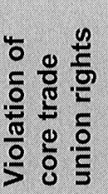 & $\begin{array}{l}\frac{5}{8} \\
\frac{8}{2}= \\
\frac{0}{0}\end{array}$ & 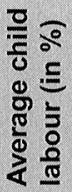 \\
\hline & & $\begin{array}{l}\text { United Arab Emirates } \\
\text { Yemen }\end{array}$ & $\begin{array}{r}2,7 \\
17,1\end{array}$ & $A, S, K$ & $\begin{array}{r}0 \\
20\end{array}$ & \\
\hline & Morocco & Morocco & 27,8 & S,D & 4 & 4 \\
\hline & $\begin{array}{l}\text { Rest of North } \\
\text { Africa }\end{array}$ & $\begin{array}{l}\text { Algeria } \\
\text { Egypt } \\
\text { Libyan Arab } \\
\text { Jamahiriya } \\
\text { Tunisia }\end{array}$ & $\begin{array}{r}29,8 \\
66,0 \\
5,3 \\
9,3\end{array}$ & $\begin{array}{r}\text { n.a. } \\
\text { A,S,K } \\
\text { A,S }\end{array}$ & $\begin{array}{r}1 \\
10 \\
0 \\
0\end{array}$ & 6 \\
\hline U & Rest of World & $\begin{array}{l}\text { Afghanistan } \\
\text { Albania } \\
\text { Andorra } \\
\text { Bermuda } \\
\text { Bosnia and } \\
\text { Herzegovina } \\
\text { Brunei } \\
\text { Cambodia } \\
\text { Croatia } \\
\text { Cyprus } \\
\text { Faroe Islands } \\
\text { Fiji } \\
\text { French Polynesia } \\
\text { Gibraltar } \\
\text { Greenland } \\
\text { Guadeloupe } \\
\text { Kiribati } \\
\text { Lao People's Dem. } \\
\text { Republic } \\
\text { Macau } \\
\text { TFYR of Macedonia } \\
\text { Malta } \\
\text { Marshall Islands } \\
\text { Micronesia, Feder- } \\
\text { ated States of } \\
\text { Monaco } \\
\text { Mongolia } \\
\text { Myanmar } \\
\text { Nauru } \\
\text { New Caledonia } \\
\text { Korea, Dem. People's } \\
\text { Rep. of } \\
\text { Papua New Guinea } \\
\text { San Marino } \\
\text { Solomon Islands } \\
\text { Tonga }\end{array}$ & 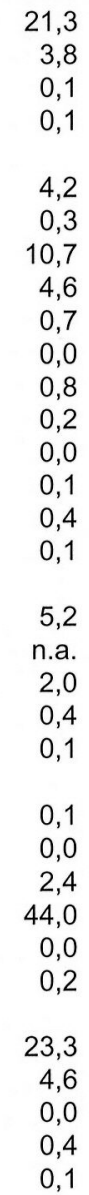 & $\begin{array}{r}\text { n.a. } \\
\text { n.a. } \\
\text { n.a. } \\
\text { n.a. } \\
\\
\text { A } \\
\text { n.a. } \\
\text { n.a. } \\
\text { n.a. } \\
\text { n.a. } \\
\text { n.a. } \\
\text { n.a. } \\
\text { n.a. } \\
\text { n.a. } \\
\text { n.a. } \\
\text { n.a. } \\
\text { n.a. } \\
\text { n.a. } \\
\text { n.a. } \\
\text { n.a. } \\
\text { n.a. } \\
\text { n.a. } \\
\text { A. } \\
\text { n.a. } \\
\text { n.a. }\end{array}$ & 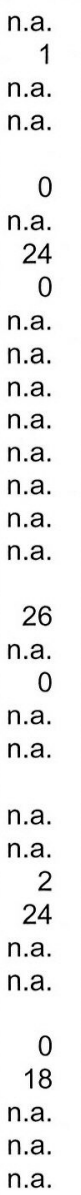 & 13 \\
\hline
\end{tabular}




\begin{tabular}{|c|c|c|c|c|c|c|}
\hline 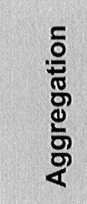 & $\begin{array}{l}\frac{5}{0} \\
\frac{0}{5} \\
\frac{\pi}{1} \\
\frac{0}{5} \\
\frac{0}{0}\end{array}$ & $\frac{2}{\grave{I}}$ & 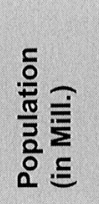 & 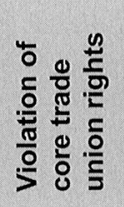 & $\begin{array}{l}\frac{5}{0} \\
\frac{0}{\pi} \\
\frac{0}{\frac{0}{2}} \\
\frac{0}{0} \\
\end{array}$ & 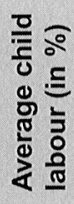 \\
\hline & & $\begin{array}{l}\text { Tuvalu } \\
\text { Vanuatu } \\
\text { Western Samoa } \\
\text { Yugoslavia }\end{array}$ & $\begin{array}{r}0,0 \\
0,2 \\
0,2 \\
10,6 \\
\end{array}$ & $\begin{array}{l}\text { n.a. } \\
\text { n.a. } \\
\text { n.a. } \\
\text { n.a. }\end{array}$ & $\begin{array}{r}\text { n.a. } \\
\text { n.a. } \\
\text { n.a. } \\
0 \\
\end{array}$ & \\
\hline C & $\begin{array}{l}\text { Brazil } \\
\text { Turkey } \\
\text { Botswana } \\
\text { Malawi } \\
\text { Mozambique } \\
\text { Tanzania } \\
\text { Zambia } \\
\text { Zimbabwe } \\
\text { Other Southern } \\
\text { Africa }\end{array}$ & $\begin{array}{l}\text { Brazil } \\
\text { Turkey } \\
\text { Botswana } \\
\text { Malawi } \\
\text { Mozambique } \\
\text { Tanzania } \\
\text { Zambia } \\
\text { Zimbabwe } \\
\text { Angola } \\
\text { Mauritius }\end{array}$ & $\begin{array}{r}161,8 \\
63,4 \\
1,6 \\
10,3 \\
16,9 \\
32,1 \\
8,8 \\
12,7 \\
12,1 \\
1,1 \\
\end{array}$ & & $\begin{array}{r}15 \\
22 \\
16 \\
34 \\
33 \\
38 \\
16 \\
28 \\
27 \\
3 \\
\end{array}$ & $\begin{array}{l}15 \\
22 \\
16 \\
34 \\
33 \\
38 \\
16 \\
28 \\
25\end{array}$ \\
\hline \multirow[t]{3}{*}{$\mathrm{U}+\mathrm{C}$} & $\begin{array}{l}\text { Thailand } \\
\text { Bangladesh }\end{array}$ & $\begin{array}{l}\text { Thailand } \\
\text { Bangladesh }\end{array}$ & $\begin{array}{r}61,2 \\
124,8\end{array}$ & $\begin{array}{l}A, S \\
A, D\end{array}$ & $\begin{array}{l}15 \\
29\end{array}$ & $\begin{array}{l}15 \\
29\end{array}$ \\
\hline & $\begin{array}{l}\text { Rest of South } \\
\text { Asia } \\
\text { Uganda }\end{array}$ & $\begin{array}{l}\text { Bhutan } \\
\text { Maldives } \\
\text { Nepal } \\
\text { Pakistan } \\
\text { Uganda }\end{array}$ & $\begin{array}{r}2,0 \\
0,3 \\
21,8 \\
131,5 \\
21,0 \\
\end{array}$ & $\begin{array}{l}\text { n.a } \\
\text { A,K } \\
\text { A,D } \\
\text { S,D }\end{array}$ & $\begin{array}{r}\text { n.a. } \\
\text { n.a. } \\
44 \\
17 \\
45 \\
\end{array}$ & 21 \\
\hline & $\begin{array}{l}\text { Rest of Sub- } \\
\text { Saharan Africa }\end{array}$ & $\begin{array}{l}\text { Benin } \\
\text { Burkina Faso } \\
\text { Burundi } \\
\text { Cameroon } \\
\text { Cape Verde } \\
\text { Central African Rep. } \\
\text { Chad } \\
\text { Comoros } \\
\text { Congo } \\
\text { Cote d'Ivoire } \\
\text { Djibouti } \\
\text { Equatorial Guinea } \\
\text { Eritrea } \\
\text { Ethiopia } \\
\text { Gabon } \\
\text { Gambia } \\
\text { Ghana } \\
\text { Guinea } \\
\text { Guinea-Bissau } \\
\text { Kenya } \\
\text { Liberia } \\
\text { Madagascar } \\
\text { Mali }\end{array}$ & $\begin{array}{r}6,0 \\
10,7 \\
6,3 \\
14,3 \\
0,4 \\
3,5 \\
7,3 \\
0,7 \\
2,8 \\
14,3 \\
0,6 \\
0,4 \\
3,6 \\
59,9 \\
1,2 \\
1,2 \\
19,1 \\
7,3 \\
1,2 \\
29,0 \\
2,7 \\
15,1 \\
10,7\end{array}$ & $\begin{array}{l}\text { n.a. } \\
\text { A } \\
\text { n.a. } \\
\\
\text { n.a. } \\
\text { n.a. } \\
\text { n.a. } \\
\text { A,D } \\
\text { A,K } \\
\text { n.a. }\end{array}$ & $\begin{array}{r}27 \\
48 \\
49 \\
24 \\
\text { n.a. } \\
30 \\
38 \\
38 \\
26 \\
20 \\
\text { n.a. } \\
\text { n.a. } \\
39 \\
42 \\
17 \\
36 \\
13 \\
33 \\
38 \\
40 \\
\text { n.a. } \\
35 \\
53\end{array}$ & 32 \\
\hline
\end{tabular}




\begin{tabular}{|c|c|c|c|c|c|c|}
\hline $\begin{array}{l}\frac{5}{0} \\
\frac{\pi}{\pi} \\
\frac{1}{8} \\
\frac{0}{3} \\
\frac{0}{4}\end{array}$ & $\begin{array}{l}\frac{5}{0} \\
\frac{0}{8} \\
\frac{\alpha}{1} \\
\frac{0}{4} \\
\frac{1}{0}\end{array}$ & $\frac{\vec{E}}{\underline{E}}$ & 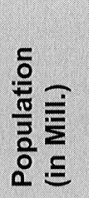 & 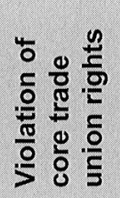 & 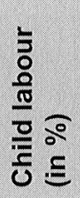 & 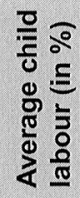 \\
\hline & & $\begin{array}{l}\text { Mauritania } \\
\text { Mayotte } \\
\text { Niger } \\
\text { Nigeria } \\
\text { Rwanda } \\
\text { Sao Tome \& Principe } \\
\text { Senegal } \\
\text { Seychelles } \\
\text { Sierra Leone } \\
\text { Somalia } \\
\text { Sudan } \\
\text { Togo } \\
\text { Zaire }\end{array}$ & $\begin{array}{r}2,5 \\
\mathrm{n} . \mathrm{a} . \\
10,1 \\
106,4 \\
6,6 \\
0,1 \\
9,0 \\
0,1 \\
4,6 \\
9,2 \\
28,2 \\
4,4 \\
49,1\end{array}$ & $\begin{array}{l}\text { n.a. } \\
\text { n.a. } \\
\text { A,D } \\
\text { n.a. } \\
\text { n.a. } \\
\text { n.a. } \\
\text { n.a. } \\
\text { n.a. } \\
\text { A,K } \\
\text { n.a } \\
\text { D }\end{array}$ & $\begin{array}{r}23 \\
\text { n.a. } \\
45 \\
25 \\
42 \\
\text { n.a. } \\
30 \\
\text { n.a. } \\
15 \\
\text { n.a. } \\
29 \\
28 \\
29\end{array}$ & \\
\hline
\end{tabular}

Sources: ELLIOTT (2000); ICFTU (several years); ICFTU (2002); OECD (1996, 2000); Schneuwly (2003); United Nations (2001b); World Bank (2000)
A) Violation of freedom of association
S) Violation of the right to strike
D) Insufficient protection of union members for discrimination
K) Violation of the right for collective bargaining

Table 14 Changes of Output Values in Scenario 1a in Percent

\begin{tabular}{|l|r|r|r|r|r|r|r|r|}
\hline Region & \multicolumn{1}{|l|}{ EU } & \multicolumn{1}{l|}{ USA } & \multicolumn{1}{l|}{ rOECD } & \multicolumn{1}{l|}{ TRANS } & \multicolumn{1}{l|}{ DEV } & \multicolumn{1}{l|}{ U } & \multicolumn{1}{l|}{ U } \\
\hline AGR & 0.66 & 0.90 & 1.58 & 0.68 & 0.56 & -3.88 & 0.46 & -3.76 \\
\hline $\mathrm{MIN}$ & -0.89 & -0.46 & -0.87 & -0.50 & -0.15 & -0.38 & -0.67 & -0.90 \\
\hline $\mathrm{IHLI}$ & 0.34 & 0.21 & 0.15 & 0.47 & 0.33 & -1.46 & 0.33 & -0.33 \\
\hline $\mathrm{IMLI}$ & 0.34 & 0.41 & 0.33 & 0.44 & 0.19 & -2.29 & 0.37 & -2.17 \\
\hline $\mathrm{IHCl}$ & 0.84 & 0.67 & 1.30 & 0.66 & 0.54 & -3.83 & 0.38 & -5.80 \\
\hline $\mathrm{IMCl}$ & 0.15 & 0.15 & 0.08 & 0.27 & 0.17 & -1.29 & 0.34 & -0.30 \\
\hline $\mathrm{SLI}$ & 0.20 & 0.29 & 0.23 & 0.17 & 0.12 & -2.20 & 0.28 & -1.63 \\
\hline SCl & 0.28 & 0.33 & 0.26 & 0.24 & 0.20 & -3.10 & 0.33 & -2.60 \\
\hline Total & 0.27 & 0.30 & 0.28 & 0.26 & 0.22 & -2.23 & 0.31 & -2.19 \\
\hline
\end{tabular}

Source: Own calculations 
Table 15 Changes of Output Values in Scenario $1 \mathrm{~b}$ in Percent

\begin{tabular}{|l|r|r|r|r|r|r|r|r|}
\hline Region & \multicolumn{1}{l|}{ EU } & \multicolumn{1}{l|}{ USA } & \multicolumn{1}{l|}{ rOECD } & \multicolumn{1}{l|}{ TRANS } & \multicolumn{1}{l|}{ DEV } & \multicolumn{1}{l|}{ U } & \multicolumn{1}{l|}{ U+C } \\
\hline AGR & 0.37 & 0.50 & 0.66 & 0.40 & 0.29 & 0.51 & -4.64 & -4.58 \\
\hline $\mathrm{MIN}$ & -0.13 & -0.09 & -0.11 & -0.02 & 0.03 & -0.08 & 0.92 & -0.07 \\
\hline $\mathrm{IHLI}$ & 0.14 & 0.13 & 0.12 & 0.23 & 0.18 & 0.16 & -1.73 & -0.38 \\
\hline $\mathrm{IMLI}$ & 0.18 & 0.18 & 0.16 & 0.22 & 0.17 & 0.16 & -2.51 & -2.74 \\
\hline $\mathrm{IHCl}$ & 0.70 & 0.41 & 0.68 & 0.52 & 0.40 & 0.72 & -5.19 & -6.79 \\
\hline $\mathrm{IMCl}$ & 0.11 & 0.14 & 0.13 & 0.18 & 0.15 & 0.19 & -2.47 & -0.85 \\
\hline $\mathrm{SLI}$ & 0.15 & 0.18 & 0.18 & 0.15 & 0.09 & 0.14 & -3.18 & -2.05 \\
\hline SCI & 0.18 & 0.19 & 0.18 & 0.19 & 0.13 & 0.15 & -3.89 & -3.33 \\
\hline Total & 0.18 & 0.18 & 0.19 & 0.19 & 0.15 & 0.21 & -3.11 & -2.67 \\
\hline
\end{tabular}

Source: Own calculations

Table 16 Changes of Output Values in Scenario 1c in Percent

\begin{tabular}{|l|r|r|r|r|r|r|r|r|}
\hline Region & \multicolumn{1}{l|}{ EU } & \multicolumn{1}{l|}{ USA } & \multicolumn{1}{l|}{ rOECD } & \multicolumn{1}{l|}{ TRANS } & \multicolumn{1}{l|}{ DEV } & \multicolumn{1}{l|}{ U } & \multicolumn{1}{l|}{ U+C } \\
\hline AGR & 0.90 & 1.18 & 1.96 & 0.92 & 0.68 & -3.68 & -3.25 & -3.56 \\
\hline $\mathrm{MIN}$ & -0.92 & -0.48 & -0.90 & -0.49 & -0.17 & -0.40 & -0.08 & -0.86 \\
\hline $\mathrm{IHLI}$ & 0.42 & 0.31 & 0.24 & 0.61 & 0.44 & -1.29 & -1.40 & -0.17 \\
\hline $\mathrm{IMLI}$ & 0.44 & 0.50 & 0.42 & 0.55 & 0.29 & -2.14 & -2.01 & -2.00 \\
\hline $\mathrm{IHCl}$ & 1.22 & 0.85 & 1.54 & 0.97 & 0.67 & -3.69 & -3.55 & -5.61 \\
\hline $\mathrm{IMCl}$ & 0.22 & 0.23 & 0.17 & 0.38 & 0.27 & -1.14 & -1.76 & -0.18 \\
\hline $\mathrm{SLI}$ & 0.28 & 0.39 & 0.34 & 0.25 & 0.18 & -2.04 & -2.35 & -1.50 \\
\hline SCl & 0.38 & 0.44 & 0.37 & 0.33 & 0.27 & -2.90 & -2.88 & -2.41 \\
\hline Total & 0.37 & 0.40 & 0.39 & 0.36 & 0.31 & -2.07 & -2.30 & -2.03 \\
\hline
\end{tabular}

Source: Own calculations

Table 17 Changes of Output Values in Scenario 2a in Percent

\begin{tabular}{|l|r|r|r|r|r|r|r|r|}
\hline Region & \multicolumn{1}{l|}{ EU } & \multicolumn{1}{l|}{ USA } & \multicolumn{1}{l|}{ rOECD } & \multicolumn{1}{l|}{ TRANS } & \multicolumn{1}{l|}{ DEV } & \multicolumn{1}{l|}{ U } & \multicolumn{1}{l|}{ U+C } \\
\hline AGR & -0.11 & -0.16 & -0.12 & -0.10 & -0.50 & -0.48 & -0.97 & -1.07 \\
\hline MIN & -0.47 & -0.40 & -0.53 & -0.35 & -0.70 & -0.61 & -0.75 & -0.92 \\
\hline IHLI & -0.01 & -0.01 & -0.03 & 0.03 & -0.59 & -0.44 & -1.06 & -0.59 \\
\hline IMLI & -0.05 & -0.04 & -0.06 & -0.03 & -0.58 & -0.45 & -1.18 & -1.41 \\
\hline $\mathrm{IHCl}$ & -0.05 & -0.04 & -0.04 & -0.05 & -0.34 & -0.33 & -0.85 & -0.81 \\
\hline $\mathrm{IMCl}$ & -0.05 & -0.04 & -0.04 & -0.03 & -0.55 & -0.40 & -1.22 & -1.30 \\
\hline SLI & 0.01 & 0.01 & 0.02 & 0.01 & -0.55 & -0.44 & -1.43 & -1.27 \\
\hline SCl & 0.01 & 0.004 & 0.01 & -0.001 & -0.68 & -0.61 & -1.86 & -1.72 \\
\hline Total & -0.01 & -0.01 & -0.01 & -0.03 & -0.55 & -0.45 & -1.26 & -1.15 \\
\hline
\end{tabular}

Source: Own calculations 
Table 18 Changes of Output Values in Scenario $2 b$ in Percent

\begin{tabular}{|l|r|r|r|r|r|r|r|r|}
\hline Region & \multicolumn{1}{l|}{ EU } & \multicolumn{1}{l|}{ USA } & \multicolumn{1}{l|}{ rOECD } & \multicolumn{1}{l|}{ TRANS } & \multicolumn{1}{l|}{ DEV } & \multicolumn{1}{l|}{ U } & \multicolumn{1}{l|}{ U } & U+C \\
\hline AGR & -0.22 & -0.32 & -0.24 & -0.20 & -1.00 & -0.95 & -1.94 & -2.14 \\
\hline $\mathrm{MIN}$ & -0.94 & -0.80 & -1.06 & -0.69 & -1.40 & -1.22 & -1.49 & -1.87 \\
\hline $\mathrm{IHLI}$ & -0.03 & -0.02 & -0.07 & 0.06 & -1.19 & -0.88 & -2.13 & -1.17 \\
\hline $\mathrm{IMLI}$ & -0.11 & -0.09 & -0.12 & -0.06 & -1.17 & -0.90 & -2.37 & -2.85 \\
\hline $\mathrm{IHCl}$ & -0.10 & -0.08 & -0.07 & -0.09 & -0.68 & -0.67 & -1.71 & -1.65 \\
\hline $\mathrm{IMCl}$ & -0.10 & -0.09 & -0.09 & -0.05 & -1.10 & -0.81 & -2.45 & -2.62 \\
\hline $\mathrm{SLI}$ & 0.02 & 0.02 & 0.04 & 0.02 & -1.11 & -0.88 & -2.89 & -2.56 \\
\hline SCl & 0.01 & 0.01 & 0.01 & -0.001 & -1.37 & -1.23 & -3.75 & -3.51 \\
\hline Total & -0.02 & -0.01 & -0.02 & -0.05 & -1.11 & -0.90 & -2.53 & -2.32 \\
\hline
\end{tabular}

Source: Own calculations

Table 19 Changes of Output Values in Scenario 3 in Percent

\begin{tabular}{|l|r|r|r|r|r|r|r|r|}
\hline Region & \multicolumn{1}{l|}{ EU } & \multicolumn{1}{l|}{ USA } & \multicolumn{1}{l|}{ rOECD } & \multicolumn{1}{l|}{ TRANS } & \multicolumn{1}{l|}{ DEV } & \multicolumn{1}{l|}{ U } & \multicolumn{1}{l|}{ U } \\
\hline AGR & -0.09 & 1.73 & -1.02 & -0.11 & 0.52 & -2.36 & -2.10 & -2.48 \\
\hline MIN & -0.39 & -0.27 & -0.45 & -0.32 & -0.22 & -0.14 & 0.11 & -0.29 \\
\hline IHLI & -0.04 & -0.06 & 0.22 & 0.27 & 0.38 & -0.70 & -0.81 & -0.25 \\
\hline $\mathrm{IMLI}$ & 0.17 & 0.06 & 0.15 & 0.05 & 0.12 & -1.10 & -1.13 & -1.00 \\
\hline $\mathrm{IHCl}$ & -0.005 & 0.64 & -0.53 & 0.29 & 0.55 & -2.50 & -2.27 & -3.90 \\
\hline $\mathrm{IMCl}$ & 0.16 & 0.09 & -0.04 & -0.21 & -0.21 & -0.76 & -1.12 & -0.30 \\
\hline $\mathrm{SLI}$ & 0.09 & 0.09 & 0.26 & 0.73 & 0.30 & -1.25 & -1.51 & -1.02 \\
\hline SCI & 0.14 & 0.11 & 0.36 & 1.02 & 0.47 & -1.70 & -1.80 & -1.60 \\
\hline Total & 0.07 & 0.11 & 0.17 & 0.40 & 0.27 & -1.25 & -1.44 & -1.37 \\
\hline
\end{tabular}

Source: Own calculations 